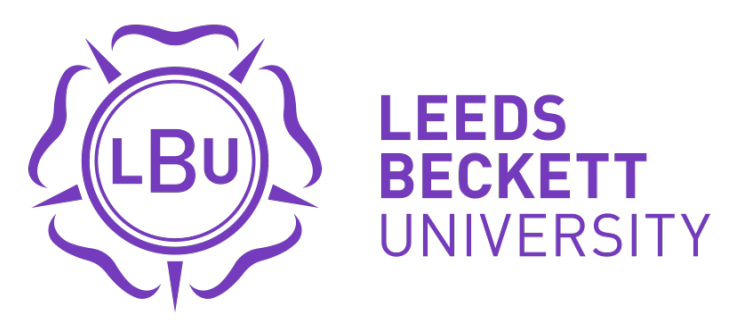

Citation:

Bradley, Q (2014) Tenants' campaigns for tenure neutrality and a general needs model of social housing: making universal claims. International Journal of Housing Policy, 14 (2). 164 - 180. ISSN 1461-6718 DOI: https://doi.org/10.1080/14616718.2014.908569

Link to Leeds Beckett Repository record:

https://eprints.leedsbeckett.ac.uk/id/eprint/21/

Document Version:

Article (Accepted Version)

The aim of the Leeds Beckett Repository is to provide open access to our research, as required by funder policies and permitted by publishers and copyright law.

The Leeds Beckett repository holds a wide range of publications, each of which has been checked for copyright and the relevant embargo period has been applied by the Research Services team.

We operate on a standard take-down policy. If you are the author or publisher of an output and you would like it removed from the repository, please contact us and we will investigate on a case-by-case basis.

Each thesis in the repository has been cleared where necessary by the author for third party copyright. If you would like a thesis to be removed from the repository or believe there is an issue with copyright, please contact us on openaccess@leedsbeckett.ac.uk and we will investigate on a case-by-case basis. 


\section{Tenants' campaigns for tenure neutrality and a general needs model of social housing: universal claims}

\section{Abstract}

The policy of tenure neutrality championed by the International Union of Tenants as essential to a right to adequate housing advances a model of general needs or universal social rented housing provision unrestricted by income limits or needsbased rationing. Support for this model has been severely undermined by recent European Commission rulings that have restricted access to social housing to those least capable of coping in a competitive market place. As general needs demand for affordable housing continues to swell, the challenge for adherents of tenure neutrality is to demonstrate that universal social housing can meet both the needs of the most vulnerable and the demands of those excluded from homeownership by price inflation and credit limits. This paper examines the promotion of universal social housing by tenants' organisations and challenges the extent to which this model is intended 'for all'. In a case study of the defence of municipal housing by English tenants' movements it identifies the exclusionary narratives that render the particular housing needs of advantaged social groups as universal. The paper concludes by reviewing strategies to resolve the tensions between the universal and the particular to reinvigorate support for tenure neutrality in arguments for widening access and supply of social housing.

\section{Keywords}

Social housing, tenants' organisations, tenure neutrality, universality 


\section{Introduction}

The concept of a universal right to adequate housing has been championed by the International Union of Tenants and supported by the United Nations Special Rapporteur (Bergenstråhle 2013; Rolnik 2013). Seen as essential to the fulfilment of this right is the policy of tenure neutrality in housing subsidies through which the International Union of Tenants posits a general needs or universal social rented housing provision unrestricted by income limits or needs-based rationing (Harloe 1995).

The concept of universality applied to public provision has been fundamentally challenged by feminist and left-wing theorists and as practical policy applied to social housing has proved deeply contentious. Tenure neutrality was one of the determining characteristics of the social democratic model of welfare state in which a widely accessible social rented sector was envisaged as an affordable and effective alternative to the market and acted as a regulatory balance to prevent inflationary cycles in house prices (Kemeny 1995). Support for this model has been severely undermined by recent European Commission rulings that have restricted access to social housing to those least capable of coping in a competitive market place. This residual model of social housing has raised concerns over the consequences for social inclusion of concentrating vulnerable and low income households in one demarcated, and subsequently stigmatised tenure (Braga \& Palvarini 2013). Policies intended to make social housing more widely available, notably in England, France and Sweden, have raised rents and threatened affordability while European states offering universal social housing services that should, by definition, be unconditional have instead operated practices of conditionality. The supposedly universal municipal sector in Sweden has excluded the most vulnerable for many years (Clark \& Johnson 2009), while in Denmark the promotion of tenant co-operatives was linked explicitly to a policy discourse around just deserts and the promotion of responsible behaviour (Jenson 1998). Meanwhile soaring house prices and private rental charges have increased demand on social housing and led to further rationing to sift the 'deserving' from the 'undeserving' in needs-based allocations (Nativel 2009; Hodkinson \& Robbins 2012). 
The International Union of Tenants (IUT) developed in the political ferment and revolutionary spirit of the 1920 s to demand 'the introduction of social rent, and housing legislation and for a prompt promotion of municipal and jointly owned housing' (IUT Assembly 1926 quoted in IUT 2013). Based in Europe, but with 64 member associations in 44 countries, the organisation is using its consultation status with the United Nations and the European Union to campaign for an affordable rented housing sector available to all. The challenge for the IUT in mobilising its campaign for tenure neutrality and gathering adherents to its cause is to demonstrate that public subsidy through social housing can provide a universal service that meets both the needs of the most vulnerable and the swelling demand from those in general need squeezed by the unaffordability of the private housing market (Fitzpatrick \& Pawson 2007).

This paper reviews the model of universal social housing advanced by the International Union of Tenants to assess the extent to which it acknowledges, and proffers solutions to these tensions between need and wider accessibility. Its focus is on the representations of universality assembled by tenants' organisations engaged in the defence of municipal housing in England. This case study provides empirical evidence of the exclusionary messages that accompany universal claims and identifies the advancement of the material interests of a comparatively advantaged social group under the mask of universal social housing. Drawing on the work of Ernesto Laclau (2007) the paper argues that tensions between the universal and the particular must be addressed if the international tenants' movement is to mobilise more successfully in support of tenure neutrality. It posits the construction of new logics of equivalence between need and wider accessibility in order to strengthen the international coalition of support for affordable housing for all.

The paper begins with a brief overview of contemporary tensions in the social housing sector in Europe, before focusing on an assessment of the situation in England. It introduces the arguments advanced around universality and tenure neutrality by the tenants' movement of that country, examining the historical base for this political representation and charting the emergence and persistence of claims around 'general needs' or universal municipal housing. The paper then explores the dialogic assemblage of the argument for 'general needs' housing by tenants' 
organisations and evidences, in contrasting accompaniment, the generation of exclusive and discriminatory discourses associated with the claim of universality. The paper concludes in an assessment of the case for social housing within tenure neutrality with a view to strengthening the arguments made for widening access and supply.

\section{The defence of tenure neutrality}

In the aftermath of the 2008 financial crisis, the collapse of private house-building and restrictions on mortgage lending triggered increased demand across Europe for affordable homes provided by municipal and not-for-profit housing organisations (CECODHAS 2011). Measures to increase the supply of social rented housing, and reverse its privatisation and disposal, were hampered, however, by the dominance acquired over European housing policy by the private property market. A series of legal challenges mounted by property developers in Sweden and the Netherlands led the European Commission to rule that public subsidies to social housing were anti-competitive unless access to the sector was restricted to those in extremes of housing need. This ruling was seen as an attack on the principles of tenure neutrality and a blow to policies of social inclusion as residual social housing sectors are associated with the spatial concentration of deprivation and poverty (Braga \& Palvarini 2013). The response in Sweden was to withdraw all public subsidies from municipal housing, undermining affordability but ensuring that the sector could continue to be open to those in general needs. In the Netherlands a maximum income limit on access to social housing was more stringently imposed to end general needs provision and potentially begin a gradual process of conversion to a residual sector restricted to the poorest and most vulnerable (Grius \& Priemus 2008).

The provision of decent affordable housing for all is central to arguments in favour of tenure neutrality advanced by the IUT (Bergenstråhle 2013). Tenure neutrality posits an economic model of supply side subsidies in which cost rental housing acts as an informal regulator of the risks, uncertainty and price irregularities of the private property market. Affordable rents are enabled by rent-pooling according to the historic cost principal (Ambrose 2006), in which the costs of building are spread 
across the whole stock of housing, enabling over time a process of 'maturation', as the cost of building new homes is increasingly offset by surplus from homes whose building costs are fully paid (Kemeny 1995). The principle of a capital subsidy that reduces the cost of housing for all tenants, without means-test, enables this model to be presented as a potentially universal service, as the partial de-commodification of housing (Harloe 1995). According to the cost rental model public subsidies can be withdrawn over time and differential rents introduced without undermining the universal appeal of the sector, in part because its competitive effect will have forced the introduction of similar high standards and affordable rents in the remaining private rental housing. This model of cost rental housing never fully achieved the universality attached to other welfare state services and support for tenure neutrality has been losing ground since the mid-1970s. Although general needs provision of social housing continues without income criteria in Denmark and Sweden, and affordable renting is accessible to middle income groups in France and Austria, the size of the sector has been significantly reduced in these countries as elsewhere in the European Union, and the promotion of private housing markets enabled the mass privatisation of social housing across the former planned economies from the 1990s onwards. In UK the municipal and social housing sector once provided for middle as well as low income households and by the 1970 s represented 30 per cent of all housing stock. A long-term policy intention to reduce the role of the municipal sector in 'general needs' housing saw successive rent increases, coupled by an expanding system of means-tested housing allowances, and from 1980 onwards huge public subsidies were provided to entice more affluent tenants to exit the sector, and speed its privatisation, while demolition and under-investment, and more recently the withdrawal of security of tenure, have threatened to restrict social rented housing to a temporary, and increasingly conditional 'ambulance' service, or refuge for the most vulnerable (Fitzpatrick \& Stephens 2008).

Tenants' organisations in England, loosely federated in a network or social movement (Grayson 1998), have long promoted municipal housing as a general needs service. The term 'general needs' in English housing policy is inextricably associated with two short periods of post-war municipal house building, in 1918 and again in 1945, addressed to meet the requirements of the skilled, organised and assertive sections of the working class, in the absence of private market solutions for 
those client groups. The role of these 'homes for heroes' in national renaissance acquired a totemic status in the collective psyche, gilding the tenure with some of the universality attached to other elements of the welfare state such as the National Health Service, state pensions, or free education (Flint 2008). The abandonment of public subsidies for general needs municipal housing was greeted by tenants organisations with violent protests in the 1930s when means-tested housing allowances were first introduced, then again in the 1960s as rents were increased to encourage the exodus of more affluent general needs tenants. Throughout that decade there were rent strikes in London boroughs and across the North and Midlands (Hampton 1970; Burn 1972, Kay et al 1977; Baldock 1982). In 1970 the London tenants' federation, the Association of London Housing Estates, set out its vision of universal municipal housing in a Tenants Charter (Craddock 1975), opposing changes in subsidy and rent policy intended to end any notion of general needs provision. When the Housing Finance Act of 1972 linked rents to market prices and brought in a national rent rebate subsidy it was greeted with nationwide rent strikes as one hundred thousand council tenants protested across the country (Sklair 1975). Tenants in at least 80 local authority areas withheld rent and rent strikers blocked roads and barricaded factories bringing traffic and production to a stand-still in support of their cause. The collapse of these protests did not undermine support in the tenant movement for the general needs model of subsidy and the launch of a new National Tenants Organisation was accompanied in 1978 by another Tenants Charter demanding social housing as a universal right (Hood \& Woods 1994). Belief in a universal and socialised rented housing provision continues to be upheld by contemporary tenants' organisations with the National Tenants Organisations arguing that 'social housing should be available to all' (Bliss 2008: 14), and the tenants' movement alliance around the campaign group Defend Council Housing arguing that social housing should be a tenure of choice, accessible to households without rationing on income or targeting on priority housing need.

The political representation of municipal housing as a universal service available to all', and therefore comparable to other welfare state provision, was strongly promoted in the years immediately prior to the 2008 financial crisis by the political campaign group Defend Council Housing . This campaign brought together tenants organisations, left wing politicians and trade unionists to oppose the transfer of 
municipal housing from public ownership to not-for-profit and profit-making registered providers in what was described as the creeping 'privatisation' of the sector (Ginsburg 2005). The work of this campaign group has been characterised as 'preservationist' (Cole 2007), in that its primary objective was to prevent stock transfer of social housing, and stop its delegation to 'arms-length' municipal housing companies. The success of Defend Council Housing was evidenced in the rejection of stock transfer or arms-length management in almost 25 per cent of tenant ballots, including high profile 'no' votes in Birmingham, England's second city and in some of the London boroughs. Calls by MPs associated with Defend Council Housing for major public investment in social housing resulted in the short-lived Local Authority New Build Programme announced in September 2009 which overturned twenty years of dis-investment to deliver new municipal house building (Robbins 2010; Lund 2011). A more fundamental achievement was the reform in 2013 of the system of municipal housing finance, the Housing Revenue Account, in which housing subsidies were unevenly distributed from centrally pooled rental income, alleged by Defend Council Housing to generate surpluses for the Treasury contrary to political claims of a sector in receipt of subsidy (House of Commons Council Housing Group 2009; CLG 2011).

Central to these victories was the ability of the tenant campaigners to assemble an attractive political representation of municipal housing that promoted the social rented sector as a destination of choice and was rooted in an idealised representation of the two exceptional periods of post-war council house building (Daly et al 2005; Mooney \& Poole 2005; McCormack 2009). They seized on the utopian discourses that had circulated at the end of World War I around estate design, quality of materials and space standards for municipal housing to coat the sector as a whole with a progressive gloss (DCH 2006; Davis \& Wigfield 2010). From the rhetoric of the post-1945 socialist Minister for Health, Aneurin Bevan, and his depiction of council housing as the 'living tapestry of a mixed community' where 'the doctor, the grocer, the butcher and the farm labourer' all lived in the same street (Foot 1997: 273) they tapped into popular memories of municipal housing as a stepup for aspirational families. The campaign's chief supporter in the House of Commons, Austin Mitchell MP tabled an Early Day Motion on Council House Building (2008) that was supported by $104 \mathrm{MPs}$, to make explicit the Bevan-like 
vision of council housing as a universal tenure. In calling for 'a new generation of first-class council housing' that would be accessible to a range of income bands, and not rationed according to the severity of housing need. Mitchell called on municipal authorities to:

'Open up their allocation policies once again to the wide range of people on council housing waiting lists so that butchers, bakers, nurses and teachers can live together with young families and pensioners thus returning our estates to the mixed and sustainable communities they used to be.'

In this political representation of municipal housing as a universal service, Defend Council Housing has been criticised for largely ignoring the failures of municipal housing and for its 'misremembering' (Bartlett 1932) of the divisive, discriminatory and sometimes oppressive manner in which council housing met its public health and welfare goals (Cole 2007). General needs post-war municipal housing was a temporary and short-lived response to the political and economic power of the skilled and organised working class at a time of market failure (Malpass 2005). A myth of universalism had been constructed and perpetuated around this limited provision by left wing supporters of municipal housing since the 1970s and the radical Community Development Programme's claim that council housing was built 'for all' (CDP 1976: 31) was echoed by Defend Council Housing in their mythic contention that 'in the past council housing provided for general housing needs of the population' (DCH 2006: 73). Unskilled and low income households were excluded from these homes since the public subsidy for house building was not enough to make rents affordable to any but those in full-time skilled employment (Glynn 2009). Access to municipal housing by these poorer social groups is traditionally blamed in popular discourse for the failure of municipal housing as a utopian experiment and its stigmatisation as a tenure of deprivation and moral decline (Card 2006).

\section{Promoting municipal housing as a universal service}

The paper now turns to primary research conducted with tenants' organisations engaged in the tenant campaigns associated with Defend Council Housing to analyse the generation of political discourse around 'general needs' provision. The aim is to examine tenant representations of a universal municipal housing service to 
determine the extent to which this purported universality is addressed to 'all'. The primary research was conducted with 151 residents in municipal and social rented housing engaged in tenants' organisations or other forms of collective housing action. It was carried out between 2008 and the end of 2012 in six English cities, and during three national tenant conventions through 15 focus groups, and ten semistructured interviews. The sample was drawn from tenants and residents associations, municipal tenants' federations, constituted tenants' panels and forums, individual tenant directors and tenants active in partnerships with social housing organisations, tenant management organisations, and regional and national tenants' organisations. Overall 55 per cent of the sample were women and around 14 per cent were from ethnic minority communities and the majority of the participants were over the age of 50 . The questions that guided the focus groups were phrased to encourage exploration of aims, grievances, mobilisation and deliberation on strategies. The questions for the interviewees focused on individual motivation, and encouraged deliberation on some of the frames of meaning that had surfaced in the group setting. Accounts in both interviews and focus groups were evaluated throughout for their consistency, and the findings were reported back to two further groups of research participants to provide an additional opportunity for triangulation while the findings were discussed at three public meetings with tenant representatives and distributed to all participants.

The research findings evidenced the joint, but largely uncoordinated construction of a vocabulary of common experience and shared interpretation among the tenant participants that was articulated individually and organised collectively. These frames were constituted by familiar reference points and story-lines with recognisable structures and meanings that could be presented as the key beliefs of a tenants' movement in England. The construction of these beliefs has been discussed elsewhere (Bradley 2012), and the task of this present paper is to analyse the distinct political representation of universal housing that emerged in those widely shared narratives. One particular framing of meaning that was extensively manifest across the research sample was the assemblage of common cause around the defence of municipal and social housing as a public good. This interpretive frame promoted the social relations of co-operation and mutual aid through an idealised model of universal social housing in opposition to what it characterised as the 
individualism of the private housing market. These beliefs were evidenced in every focus group and interview but they were translated into defined political contentions in discussions with federal tenants organisations, and an analysis of debate in two specific tenants' federations is presented in this and following sections to explore the construction of these claims in detail. 'Federation A' is actively engaged in Defend Council Housing, and in national tenants campaigns while 'Federation B' was established in defence of municipal housing and is one of the founders of the Tenants \& Residents Organisations of England (TAROE), a member of the International Union of Tenants. The discussions in these focus groups took place between members active in these campaigns and questions were phrased in order to encourage the participants to articulate and question their support for universality in social housing and to debate their goals and strategies in the campaign for tenure neutrality. It should be understood that these views were widely held across the nationwide sample of 151 residents, although sometimes in less explicitly political terms, and the selection of data from these two organisations is made only to enable the dialogic assemblage of these universal claims by tenant organisations to be identified and explored in depth.

The defence of a universal model of municipal housing provision by tenants' organisations appears to be based on personal experience of living in the high quality homes of post-war general needs council housing. The membership of tenants' organisations in England is composed, in the main, of residents of retirement age, and research with this age group commonly reveals personal connections between municipal housing and social mobility, demonstrating the important role social housing played in post-war childhoods (Lupton et al 2009). A focus group of eleven people from Federation A, five women, six men, the majority born in the 1940s or 1950s, reminiscing about their early experiences of municipal housing remembered mixed income estates, there 'was no stigma', 'it was a step up' from the private rented sector, 'there was a cross section of normal people living in a row of council houses, and they were fine, wonderful houses'. Their narratives are constructed around two frames of comparison, but only one, the contrast with standards in the private sector, is overtly stated. The other is implied by the references to the lack of stigma of these first remembered council estates, the references to 'normal people', who, it was said, 'took care of their homes'. This 
reference point though not overt appeared readily understood by all the participants and became more apparent as the discussion in Federation A continued its reminiscences:

Patricia: I think the big difference that I noticed, when I came into a council house at the beginning of the war, and of course everything was wonderful at first. [..]. Everyone cared for those houses, regardless. Everyone joined together, if anyone was in difficulties, everyone rallied round. You don't get this anymore. Nobody cares about the property. It's a case of oh, it's a council house, let them deal with it. We didn't in those days.

The familiar tale that a 'golden age' of general needs municipal housing was succeeded by a stigmatised welfare service is a consistent theme in English housing studies (see Clarke \& Ginsburg 1975; Cole \& Furbey 1996). In these accounts the decline of municipal housing, characterised as a process of residualisation, results from a change in the social composition of tenants, as increasing numbers of households not in full-time paid employment entered the social rented sector. An excluded section of the working class, particularly households headed by lone women, ethnic minorities and disabled people moved from the invisibility of the slums to become the subjects of political policy in the spotlight of council housing from the 1930s, and again from the late 1950s as subsidies were aligned to public health goals. These marginalised and economically powerless households were relegated to the worst properties by the grading work of the housing visitor who quickly determined 'rough' from 'respectable' (Rex \& Moore 1967). They were housed in patched-up council-owned slums, damp and freezing high rise flats, or badly maintained and stigmatised estates while households judged of good conduct were awarded the high-quality and spacious municipal housing built during the 1920s and 1940s. Selection on good behaviour, good housekeeping and just deserts dominated access to municipal housing until the Cullingworth Report in 1969 recommended needs-based allocations (Somerville 2001). Even then local authorities continued to divide the council stock according to the merit of tenants, ensuring the poorest and most vulnerable, and especially the 'non-working class', were marginalised in the worst houses or flats (Damer 1989). The division between 'rough' and 'respectable' has been an enduring theme in working class culture and the distinction was made tangible in municipal housing by divisive and discriminatory 
practices of housing management, endorsed by those tenants who benefited from better quality housing as a result (Jacobs 1981). As long as the 'undeserving' could be marginalised to sink estates, and the high quality housing remained reserved for 'respectable' tenants, an ideal of universal municipal provision could be preserved. The assertion that municipal housing was once intended 'for all' is based on the exclusion of many, and entails the operation of firm divisions between the needs of the 'respectable' and those deemed not so 'deserving'.

It was the shift to primary allocation on criteria of housing need that provided incontrovertible evidence of the residualisation of municipal housing and its loss of universal appeal (Lupton et al 2009). Contemporary tenant campaigners date the process of residualisation around the key point of the 1980 Right to Buy, the sale of municipal housing at huge discounts to sitting tenants (DCH 2006; DCH 2008). Right to Buy was aimed specifically to appeal to those general needs tenants in the best quality homes with the most financial means. Home ownership had gained ground with the working class in the 1930s, but from the 1950s onwards governments channelled public subsidies and directed tax breaks to encourage the more affluent households to enter the private market; a carrot supplemented by the stick of increasing rents. Sales of municipal housing were a key aspect of this policy, but the 1980 Housing Act for the first time awarded tenants the conditional right to buy their home with generous discounts (Jones \& Murie 2006), a policy that removed 2.5 million houses from public supply. The discussion in Tenants' Federation A articulates a clear account of the consequences of this policy and the radical change in the social composition of tenants that supposedly ensued. In this account the degeneration of municipal housing is associated with a decline in the affluence but also the 'respectability' of tenants. The first speaker presents the change in the composition of tenants as a migration of the better off into home ownership.

Jim: The problems really started when Mrs Thatcher became PM of this country. She was the one who brought in the Right to Buy. Before that time people who lived in council houses, as they said, they were mixed, teachers and all sorts of people, lived together in a community. But when they started to get their mortgages and move out, we were left with the people who were more poor than those who moved out. 
The second speaker, Michael, makes it clear that the difference between two sets of tenants is not about income. Instead it is characterised by behaviour.

Michael: When Maggie Thatcher's Right to Buy came along, all the - I don't mean this in the, the right way - all the decent people, the people who did look after their houses were encouraged to move off the council houses and buy their own houses away from the council estates. So sadly this is what is left, is all the people who are on social housing, are on unemployment benefits and are subject to outbursts of crime.

There are the 'decent people' who look after their houses, and there are those who do not, as Michael continues to explain.

Unfortunately on these estates most of the people have found out, the teachers, the doctors, the nurses who used to live, who were brought up on these estates have, dare I say, have bettered themselves and moved away from the estates and they were the people that was the hope of, of the community. And they've all left and the estate is an empty shell.

It should be no surprise that assertions of distinctions between 'deserving' and 'undeserving' are common to the narratives of social housing tenants when the selection processes of municipal housing managers enshrined them over generations as routine practice. For many tenants these narratives reflect their personal experience of declining living standards and the intensification of poverty in municipal housing. The concentration in the social housing sector of people on very low incomes, reliant on pensions and benefits, became increasingly noticeable from the 1980s onwards, although the process began much earlier, and the Right to Buy was successful in skimming off the best quality 'general needs' post-war housing from the stock (Jones \& Murie 2006). In the discourse of tenant campaigners, this process of residualisation is associated with the rise of 'undeserving' behaviour, and it is the migration from the sector of those tenants graded 'deserving' and 'respectable' that causes decline. 


\section{$\underline{\text { Universal claims, sectoral interests }}$}

When tenant campaigners claim that municipal housing was, in the past, available to 'all' they promote the specific material interests of a particular sector as universal since post-war, high quality municipal housing was only available to those in wellpaid full-time employment. The advancement of the sectoral interests of that group as universal entails the consequent exclusion from the concept of universality of those whose needs cannot be addressed: the low waged or unwaged, lone parents and ethnic minority households excluded from the best quality municipal housing. Once removed from the concept of universality these social groups are rendered a non-people and can be excluded from consideration as 'undeserving'. The universal represents the specific needs of a particular group advanced as if they represented the needs of all. As Laclau (2007: 35) suggested: 'the universal has no necessary body and no necessary content: different groups, instead, compete between themselves to temporarily give to their particularisms a function of universal representation'.

The assemblage of the representation of social housing as universal - as provision 'for all' - is associated with demands that it should be available to meet the particular needs of higher-earning or at least comparatively affluent tenants. This argument is evidenced in analysis of another discussion between members of Tenants' Federation A. This group involves nine people, seven women and two men, again all born in the 1940s and 1950s. The discussion begins with the claim that social housing was initially intended to house the more affluent working class, and not the poorest in society.

Joan: We know the social housing idea came out, so's it was, um, a liveable rent, somewhere for someone to go, not actually the poor and the needy, because there was other houses that were there at that time for somebody on the poverty line. No but the ordinary normal social housing was for someone that probably had a reasonable income and could pay the rent and if they fell on hard times then they could apply for subsidence.

Mike: Social housing unfortunately, decided that if you are earning a little bit of money, the doctrine that was put out, that you should go and buy your property, 
now all kinds of false subsidies were made to help you do that. So social housing, renting, should still be a human right. And we're missing out on so much.

This discussion took place during a period of consultation over government proposals that high earning council tenants in England should 'pay to stay' meaning that those earning over $£ 50,000$ a year should pay higher rents (CLG 2012). Joan's comments on this proposal are illuminating in the light of her earlier statement that social housing was intended for those with 'reasonable' incomes:

Joan: Well for somebody that was earning millions then I would say, yes, go buy yourself a mansion but if you're not on the million side of it or say you get to about $£ 30,000$ or $£ 40,000$, they're on about $£ 50,000$ and you have to leave your own home, well I don't think, $£ 50,000$ these days you can easily keep that in your pension fund, you know?

Nancy: (Laughs)

The contention that social housing was never intended for the poorest, that its natural constituency is those on 'reasonable' incomes, meaning those earning $£ 50,000$ and hence twice the average full-time wage, suggests the colonisation of the universal by a better off segment of the working class. The statement that social housing is meant for people with 'a reasonable income' is immediately followed by Mike's contention that social housing is a human right. The universalism of social housing is, in this case, explicitly limited to people 'earning a little bit of money'. These arguments are mirrored in a focus group held with Federation B. Here eight committee members, three women and four men, identify a demand for social housing from those excluded from home ownership by the unaffordability of mortgage lending.

Danny: If you are looking at the best things about social housing it is a fact that it provides accommodation for people that due to circumstances will never be able to have their own home. And it also helps them to have a place where they can raise a family, stuff like that.

Keith: Also social housing is probably the only housing that some people can afford. No way can they afford mortgages or stuff like that. And with the welfare 
benefits system that helps people to get the rent paid out of benefits where if you owned the house you wouldn't get the same type of benefits to help you to run it.

Patricia: And do you not think there's going to be a lot more people wanting social housing that previously had owned their own houses?

Christine: Yes

Patricia: Because they're not going to be able to pay the mortgage.

In positioning council housing as an option for potential homeowners excluded from the market, members of the focus group go on to establish claims to universality that are explicitly connected to the rights of the most affluent. Asked who council housing is for, the response was:

Patricia: People who can't afford mortgages.

Keith: People who are on incomes that are insufficient to pay for a mortgage.

Paul: Well it's actually for everybody

Richard: I mean it is basically for everybody is social housing. It doesn't matter what your income. You can apply for social housing. People with high incomes won't do it, but they could do.

At the height of the economic crisis triggered by the sub-prime mortgage market and the collapse of banks across USA, Iceland and UK in 2008, a deposit of 20 per cent or at least $£ 25,000$ was routinely demanded by banks and building societies in England to secure mortgage lending, putting home ownership out of reach of all firsttime buyers, except those with inherited wealth from 'the bank of mum and dad'. The discussion among members of Federation $B$ reflects this affordability crisis, and the cost of mortgage lending becomes the meter through which these tenants' federation members express the universality of social housing. The reference to 'people on high incomes' who could also access social housing but chose not to do so, posits an equivalence between those temporarily excluded from homeownership and those for whom homeownership will never be attainable. These federation members refer explicitly to the interests of a sector of the market who aspire to home ownership but 
find themselves temporarily excluded from mortgage lending. They appeal to a model of general needs housing that provides for the aspirational and most affluent sections of the working class and they portray the satisfaction of the specific interests of that particular sector as a universal right.

\section{Tenure neutrality and universal rights to housing}

This analysis of the political representations of universality in social housing by tenant campaigners in England suggests the assertion of false claims to historical precedent to portray an exclusionary service as once available to all. The decline of municipal housing is attributed in this shared narrative to the entrance into social housing of those whose lack of economic power and social status enabled them to be excluded from the universal. Arguments are marshalled to promote privileged access to social housing for those in middle incomes and to assert uncomplicated equivalences between the interests of the more affluent and those in extreme housing need. These claims to universality emerge from the specific economic and social pressures on the aspirations of would-be home owners faced with the deliberate inflation of a price bubble in housing costs matched by chronic shortage of supply. The context for a universal right to housing is posited on the needs of a relatively affluent sector of the population, identified by one participant as those in receipt of twice the average income. The needs of this particular sector are asserted as expressing the totality of housing need, suggesting the exclusion from discourse of the most vulnerable and the least affluent. The particularity of these universal demands is reinforced by a history of institutional discrimination in municipal housing allocations through inspection and selection and in the maintenance of distinctions between deserving and undeserving over many decades. The failure of these tenants' organisations to challenge the implicit and sometimes explicit discrimination in the construction of their universal claims aligns the campaign for universal housing and tenure neutrality with political discourses of conditionality that privilege notions of desert over need.

Universal claims are established, Ernesto Laclau (2007) argues, by forging logics of equivalence between the particular needs of social groups or sectors. The campaign 
for universal social housing in England has attempted to mobilise support for its goals by demonstrating a logic of equivalence between the thwarted aspirations of would-be homeowners, and the need for decent affordable housing for all. This equivalence is established through a process of exclusion in which those in most housing need, who have least economic power and social standing, are marginalised to the point of invisibility. These universal claims do not result, therefore, in a broadening of access to social housing but in a hardening of its conditionality and a reduction of its affordability, as a higher income sector establishes its right to housing. The universal is an inherently unstable and contingent political project; it is an exercise in power and an attempt to fix meaning and identity. The task for those making universal claims and asserting universal rights is, for Laclau, to articulate logics of equivalence around those conventionally excluded from this political project. The universal arises from the particular but to appear universal the particular has to demonstrate its identification with the plurality; it has to acknowledge its specificity and become what unites everyone. In Laclau's framework, social housing must first become a cause of unity before it can become universal. Rather than asserting the interests of a particular sector as universal, tenant campaigners could seek to identify a commonality between social groups in their requirement for affordable housing. They could attempt to establish logics of equivalence between the needs of those with least economic power and the desires of the more affluent but still poorly housed. This would mean finding common ground between conflicting discourses of social justice, between merit and human need, between rewarding responsible behaviour and making restitution for disadvantage. This project would entail the recognition and repudiation of traditions of exclusion and moralised conditionality in the English social housing sector. It would require the assemblage of political representations of social housing that do not depend on partial and incomplete accounts of its post-war history.

\section{$\underline{\text { Conclusion }}$}

In the promotion of tenure neutrality the International Union of Tenants advances an argument over the fair and efficient use of public subsidy to provide affordable housing for all. The IUT is attempting to mobilise support for a universal model of social housing that appears contrary to recent European Commission rulings that 
have favoured market solutions for general needs demand. While the principle of universal social housing has been promoted by tenants' organisations and social democratic parties in some European states, its actual provision has been mediated often by conditionality or rationed according to income or degrees of housing need. In a case study of the English tenants' campaign for a general needs municipal housing sector this paper has identified the 'misremembering' that has allowed a partial and exclusionary provision to be idealised as universal, and, in the arguments of tenants campaigners it has evidenced the unchallenged persistence of discriminatory discourse that renders the universal conditional. It has pointed to the equivalence forged between the needs of more affluent social groups and the universal right to affordable housing. The case study suggests the campaign for tenure neutrality can be undermined by a historic failure to address the conflicts and tensions between discourses of desert and need. In generating debate in public policy around principles of universality in social housing the International Union of Tenants needs to reconcile the efficient targeting of public subsidies with the social justice of wider access to decent affordable housing. This is a difficult task of confronting the conflicts between social groups and assembling a plurality that does not exclude the least vocal and most vulnerable. Acknowledging the specificity of the universal would appear to be the first stage in advancing a blueprint for a right to housing that can be truly available to all. 
Bibliography

Ambrose, P. (2006) What is the Housing Problem?, in: Defend Council Housing (ed.) The Case for Council Housing in 21st Century Britain. Nottingham: Russell Press.

Baldock, P. (1982) The Sheffield Rent Strike of 1967-8. The Development of a Tenants' Movement. In: Henderson, P., A. Wright \& K. Wyncoll (eds.) Successes \& Struggles on Council Estates. London, Association of Community Workers.

Bartlett, F. C. (1932) Remembering: a study in experimental and social psychology. Cambridge: Cambridge University Press

Bergenstråhle, S. (2013) The right to housing and the need for tenure neutrality. Global Tenant. April, p.3. Stockholm, Sweden. International Union of Tenants

Bliss, N. (2008) Developing Housing Strategy in a Post-Credit Crunch World. Liverpool. TAROE, CCH \& NFTMOs

Bradley, Q (2012) Proud to be a tenant: the construction of common cause among residents in social housing. Housing Studies. Vol. 27. No. 8: 1124-1141

Braga, M. \& P. Palvarini (2013) Social Housing in the EU. Brussels, Policy Department A: Economic \& Scientific Policy. European Parliament.

Burn, D. (1972) Rent Strike St Pancras 1960. London. Pluto Press.

CDP (1976) Whatever happened to council housing? London: C.D.P. Information and Intelligence Unit

CLG (2011) Implementing self-financing for council housing. London. Department of Communities \& Local Government.

CLG (2012) High Income Social Tenants Pay to Stay. Consultation paper. London. Department of Communities \& Local Government 
Card, P. (2006) Governing Tenants: from dreadful enclosures to dangerous places. In: Flint, J. (ed.) Housing, Urban Governance and Anti-Social Behaviour. Bristol. The Policy Press.

Clark, E. \& K. Johnson (2009) Circumventing Circumscribed Neoliberlaism: the system switch in Swedish Housing. In: Glynn, S. (ed.) Where the other half lives. London. Pluto Press

Clarke, S. \& N. Ginsburg (1975) The Political Economy of Housing. Political Economy and the Housing Question. Papers presented at the Housing Workshop, London. Conference of Socialist Economists

Cole, I \& R. Furbey (1994) The Eclipse of Council Housing.London. Routledge.

Cole, I. (2007) What future for social housing in England? People, Place \& Policy Online: 1/1, pp. 3-13

Council House Building (2008) HC Early Day Motion 355 2008-09

Craddock, J. (1975) Tenant's Participation in Housing Management: a study of four schemes. London. ALHE

Daly, G., Mooney, G., Poole, L., Davies, H. (2005) Housing Stock Transfer in Birmingham and Glasgow: The Contrasting Experiences of Two UK Cities. European Journal of Housing Policy, Vol. 5, No. 3, 327-341

Damer, S. (1989) From Moorepark to 'Wine Alley'. Edinburgh. Edinburgh University Press

Davis, C. \& A. Wigfield (2010) Housing: Did it Have to be Like This? A Socialist Critique of New Labour's Performance. Socialist Renewal No. 53, Eighth series, No. 3. Nottingham, Spokesman Books.

DCH (2006) The Case for council housing in 21st Century Britain.London. Defend Council Housing

Fitzpatrick, S. \& H. Pawson (2007) Welfare Safety Net or Tenure of Choice? The Dilemma Facing Social Housing Policy in England. Housing Studies, 22:2, 163-182 
Flint, J. (2008) Welfare state institutions and secessionary neighbourhood spaces. In: Flint, J. \& D. Robinson (eds.) Community cohesion in crisis: new dimensions of diversity and difference. Bristol. Policy Press, pp.159-176

Foot, M. (1973) Aneurin Bevan: a biography (Vol. II). London. Davis-Poynter

Ginsburg, N. (2005) The privatization of council housing. Critical Social Policy; 25; 115-135

Grayson, J. (1997) Campaigning tenants: a pre-history of tenant involvement to 1979. In: Cooper, C. \& Hawtin, M. (eds.) Housing, Community and Conflict: understanding resident involvement. Aldershot, Ashgate Publishing.

Gruis, V. \& H. Priemus (2008) European Competition Policy and National Housing Policies: International Implications of the Dutch Case. Housing Studies. Vol. 23:3, 485-505

Hampton, W. (1970) Democracy and Community: a study of politics in Sheffield. London, Oxford University Press.

Harloe, M. (1995) The people's home? : social rented housing in Europe and America. Oxford. Blackwell.

Hodkinson, S. \& G. Robbins (2012) The return of class war conservatism? Housing under the UK Coalition Government. Critical Social Policy 2013 Vol.33. No.1: 5777 First published online15 October 2012

Hood, M. \& R. Woods (1994) Women and Participation. In: Gilroy, R. \& R. Woods (eds.) Housing Women. London. Routledge

House of Commons Council Housing Group (2009) Council Housing - time to invest. Paper 1 The Case for Council Housing. London. House of Commons Council Housing Group

Jacobs, S. (1981) The Sale of Council Houses: Does It Matter? Critical Social Policy. Vol. 1: 35-48 
Jones, C. \& A. Murie (2006) The Right to Buy: analysis and evaluation of a housing policy. Oxford. Blackwell.

Kay, A. M. Mayo \& M. Thompson (1977) The United Tenants Action Committee. In: Cowley, J., A. Kay, M. Mayo, M. Thompson. Community or Class Struggle? London. Stage 1

Kemeny, J. (1995) From public housing to the social market : rental policy strategies in comparative perspective. London. Routledge.

Laclau, E. (2007) Emancipation(s). London. Verso

Lund, B. (2011) Understanding Housing Policy. Bristol. The Policy Press

Lupton, Ruth et al (2009) Growing Up in Social Housing in Britain: a profile of four generations 1946 to the present day. London, Tenant Services Authority.

Malpass, P. (2005) Housing \& the Welfare State. Basingstoke. Palgrave Macmillan.

McCormack, J. (2009) 'Better the Devil You Know': Submerged Consciousness and Tenant Participation in Housing Stock Transfers. Urban Studies. 46: 2, 391-411

Mooney, G. \& L. Poole (2005) Marginalised voices: resisting the privatisation of council housing in Glasgow. Local Economy,20:1,27 - 39

Nativel, C. (2009) The Politics of Housing under France's New Right. In: Glynn, S. (ed.) Where the Other Half Lives. London. Pluto Press

CECODHAS (2011) Housing Europe Review 2012. Brussels (Belgium). CECODHAS Housing Europe.

Rex, J. \& R. Moore (1967) Race, Community \& Conflict. London. OUP Robbins, Glyn (2010) Arguments for a renaissance of municipal housing. Paper presented to the Housing Studies Association Conference, York University $14-16$ April 2010. [Internet] Available at <http://www.york.ac.uk/chp/hsa/conference.htm> Accessed 15January 2013 
Rolnik, R. (2013) Report of the Special Rapporteur on adequate housing as a component of the right to an adequate standard of living, and the right to nondiscrimination in this context. United Nations General Assembly, $68^{\text {th }}$ session. A/68/289

Sommerville, P. (2001) Allocating Housing or 'Letting' People Choose. In: Cowan, D. \& Marsh, A. Two Steps Forward. Bristol, The Policy Press. 